\title{
Correlation Between Social Status and Health in Early Medieval Dalmatia
}

\author{
Vlasta Vyroubal, Željka Bedić, Anita Adamić Hadžić, Mario Šlaus \\ Anthropological Centre, Croatian Academy of Sciences and Arts, Zagreb, Croatia
}

\begin{abstract}
A B S T R A C T
The early mediaeval period in Croatia is rarely mentioned in historical sources. The development of society during this period was greatly influenced by formation of communities, within which there were many inequalities. The social group one belonged to and its ordinance were the main factors in the material and spiritual life of mediaeval man. Within Croatia, during the Early Middle Ages the process of social disintegration and the formation of social groups/ strata varied from area to area. However, it can be deduced that this process was the quickest and most complete in the most socially-developed area - the Eastern Adriatic coast. The basic hypothesis of this paper is that people who belonged to different social groups also had different living conditions, which was reflected in their health, quality of life and lifespan. An individual's social status was assessed using the archaeological context, i.e. form of burial. The assumption was made that differences in status were reflected in the manner of the burial. The criteria used to determine social status were grave architecture and quantity and quality of grave finds and goods. In order to assess the health of the individuals anthropological methods were used. These methods included the assessment of age and sex, as well as the analyses of pathologies that leave traces on dry bones. Multivariate statistical methods showed that even though there were social inequalities in the early mediaeval society, the individuals belonging to higher-ranking groups had neither better health, nor lived longer. The results of the analyses carried out in the course of this work show that even though social stratification did exist in the early mediaeval society, biological sex was a much more important factor in life expectancy and quality of life than which social group an individual belonged to.
\end{abstract}

Key words: bioarchaeology, social status, biological health, Early Medieval period, Dalmatia

\section{Introduction}

Social standing, social status, or socioeconomic status is the position that an individual occupies in a particular social group or social structure, according to his/her origin, economic power, personal abilities, and education. Social status determines values, rights, power and limitations, which is reflected in various appropriate symbols ${ }^{1}$. The social community was crucial for the development of the medieval society in Croatia, and urban and rural communities were basic forms of people association. Both rural and urban societies were striving toward community formations. Social security of a community was generally more modest in rural areas, and that insecurity was most pronounced in times of adversity. Members of the community lived, created their institutions and structures, and raised their families on its territory. The community as such was an irreplaceable shelter in the everyday life of a medieval man or woman. The rural community was always a part of an aristocratic estate, church estate, or city district. Even in the most developed communities members of these communities have gathered in undefined yet recognisable groups ${ }^{2}$. This is considered to be the beginning of social groups formation in the Croatian Middle Ages. It began with the emergence of a separate group of individuals who differed from most of the other community members by material and legal position.

In modern populations, the socioeconomic status of adults is measured by education (usually in years), occupation, and annual income. Social status in children is, on the other hand, measured not just by family income, but also with other forms of social status in the community such as various contacts with the community, membership in certain associations, perception of the family by the community, etc. ${ }^{3}$. According to Weber, status is determined by

Received for publication February 4, 2020 
the level of honour and prestige, in other words, status is a social reputation which is conditioned by a specific lifestyle. Various researches by sociologists, psychologists, economists, demographers, epidemiologists and other experts confirm that people with higher social status enjoy better living conditions, which has a positive effect on their health ${ }^{4}$. Research conducted on modern populations has also shown that social status is associated with the frequency and distribution of the disease and mortality ${ }^{5-7}$. Inequalities in the health of the population which are the result of social differences are most evident through the mortality and morbidity of specific community subgroups ${ }^{8}$. Social groups with fewer resources are at greater risk of being exposed to different pathogens, and therefore have significantly poorer health ${ }^{9}$. Personal characteristics such as sex, age, and social status are strong mediator variables that affect not only people's living conditions but also their expectations and values, that is, their subjective conception of what makes good or bad quality of life ${ }^{10}$.

The most detailed and comprehensive research on the relationship between health and social status in an archaeological population was conducted by Powell in $1998^{11}$ on osteological material from the Moundville site in the United States. Moundville was one of the most important centres of the Mississippi culture in Alabama in North America between 1050 and 1550. Systematic research of the site lasted for almost a hundred years during which time more than 3,000 graves were excavated and analysed. When defining social status based on the archaeological context, Powell used the results of grave goods analysis carried out by archaeologists Peebles and Kus ${ }^{12-}$ ${ }^{13}$. Through her research, she identified evidence of clear social stratification in Moundville, which led her to explore the correlation between health and social status clearly, to the extent in which "health" can be determined in osteological material ${ }^{11}$. Her research was based on the analysis of various physical indicators that affect health. A similar study was conducted on osteological material from an archaeological site closer to Croatia, Pontecagnano in southern Italy ${ }^{14}$. Pontecagnano is located on the Italian coast, about $60 \mathrm{~km}$ south of Naples, and dates back to the period between the $7^{\text {th }}$ and $3^{\text {rd }}$ centuries $\mathrm{BC}^{15-25}$.

The results of such analyses are relatively similar to those concerning modern populations - primarily in the sense that the relationship between social status and health is rather complex. Besides the study by Powell, numerous other studies deal with this kind of research: "Social Dimensions of Mortuary Practices in a Mesolithic Population from WadiHalfa, Sudan"26; "The Incidence of Diffuse Idiopathic Skeletal Hyperostosis and Social Status Correlations in Lithuanian Skeletal Markers"27; "Biological Evidence for Social and Temporal Differences in Diet at Piedras Negras, Guatemala"28; "Status and Health in Roman Dorset: The Effect of Status on Risk of Mortality in post-Conquest Populations"29; "Health of the NonElites at Tombos: Nutritional and Disease Stress in New Kingdom" 30 ; "Investigating Health at Kerma: Sacrificial versus Non-Sacrificial Individuals" ${ }^{31}$.
The main goal of this study is to determine whether there is a correlation between privileged social status and "better health" in the medieval Nin - Ždrijac skeletal series. This correlation will be determined based on the absence of various osteological and dental indicators of physiological stress on osteological material from the site. The main hypothesis of this study is that individuals of lower social status lived in poorer living conditions than individuals belonging to a higher social class. Stresses that affect an individual's health are inadequate nutrition, greater exposure and susceptibility to diseases, generally worse living conditions, insufficient medical care, longterm hard physical labour, and the frequency and distribution of trauma. The underlying presumption behind this is that the health consequences that these stresses cause result in changes that stay visible in the skeletal remains of the deceased.

The logical assumption is that individuals that belonged to higher social status were not as exposed to pathogens that affect health and quality of life as individuals of lower social status. The basic assumption which is the foundation of this study is that the individual's social status can be deduced as it is reflected in its funerary ritual and the amount and quality of archaeological artefacts that are buried with it ${ }^{25,32}$. There were strict rules in most archaeological populations regarding the burial of the deceased. The type of burial, grave architecture, position and orientation of the deceased, horizontal stratigraphy, quantity and quality of grave goods reflect the wealth, i.e. the social position of the deceased ${ }^{33}$. In other words, the ritual by which the deceased is seen off from this world is the reflection of the social status they enjoyed in life.

\section{Material and Methods}

The archaeological site Nin - Ždrijac is considered to be one of the most important sites in Croatia. It has a continuity of life from the Neolithic period to the present day. Systematic archaeological excavations of the site began in 1969 under the direction of Janko Belošević and the Archaeological Museum in Zadar, and continued up till $1977^{34}$. In six campaigns 337 graves were excavated and investigated. The cemetery is dated to the $8^{\text {th }}$ and first half of the $9^{\text {th }}$ century, and in terms of the archaeological finds and funerary architecture, it can be classified as a settlement cemetery organised in rows ${ }^{35}$. Through the study of horizontal stratigraphy, it is possible to perceive individual groups of graves formed most probably based on family relationships or clan membership. The most obvious example of such groupings can be found in the eastern part of the cemetery, where a certain number of graves was concentrated around grave 332 in which an early high-ranking family was buried ${ }^{36}$.

Grave goods found in the cemetery can be divided into several categories: cult goods, high-status artefacts (e.g. jewellery and personal adornment), armour, weaponry and tools. The most common finds in the site are pottery, wooden bowls, glassware/glass vessels and other everyday items (e.g. knives, folding knives, razors, flintstones, iron 
keys, bone combs). Weaponry found at this site includes a double-edged sword, spears, combat knives, arrowheads, horse and harness equipment. Jewellery items mostly include earrings, rings, necklaces, ring-shaped necklaces, and lockets ${ }^{37}$.

Anthropological analysis was conducted on 216 skeletons. Sex determination was established based on the differences in cranial and pelvic morphology ${ }^{38-40}$. Age at death in adults was estimated using pubic symphysis morphology ${ }^{41}$, auricular surface morphology $y^{42}$, ectocranial suture closure ${ }^{43}$, sternal rib end changes ${ }^{44,45}$, and dental attrition ${ }^{46}$. The age of subadults was determined based on the development and formation of deciduous and permanent teeth, the degree of bone ossification, and the length of the diaphysis of long bones ${ }^{47,48}$.

In order to obtain a comprehensive picture of health, the presence of the following pathologies were analysed: cribra orbitalia, dental enamel hypoplasia, caries, vertebral degenerative osteoarthritis, Schmorl's nodes and traumas. Cribra orbitalia manifests as porous, slightly elevated bone on the superior orbital roof. It is usually considered to be the result of anaemia due to iron deficiency caused by numerous factors such as endemic parasitism, chronic gastrointestinal ailments, inadequate diet or unhygienic living conditions. Although cribra orbitalia is generally caused by megaloblastic and hemolytic anaemias, paleopathological studies debate that these lesions, which cause subperiosteal bleeding, have a more complicated aetiology. These pathological processes are frequently associated with scurvy, rickets, hemangiomas, and traumatic injuries that produce subperiosteal hematomas, and in the end, lead to orbital roof lesions ${ }^{49-51}$.

Dental enamel hypoplasia (DEH) is a disturbance in the creation of an organic matrix of the enamel, which is recognizable by thin enamel, usually presenting as transverse furrows or pits ${ }^{52,53}$. Enamel hypoplasia is a subadult disorder caused by acute stress and is usually associated with malnutrition, vitamin A, C and/or D deficiency, and presence of anaemia and psychological and/or physical trauma ${ }^{54-57}$. As dental enamel hypoplasia usually occurs on the anterior teeth (incisors and canines), the frequency data for DEH in the analysed sample were obtained for the central incisors of the upper jaw and the canines on the left side of the upper and lower jaws. If this tooth was missing, its right-side equivalent was analysed. The frequency data were collected for adults only.

Dental caries is localised demineralisation of dental hard tissues by organic acids (usually Streptococcus mutants and Lactobacillus acidophilus) that develop as a result of bacterial fermentation of dietary carbohydrates. Caries frequency is therefore correlated with diet; high caries rates are typically correlated with greater consumption of carbohydrates, whereas low rates of caries are correlated with low carbohydrate diets. The reason for this is that microorganisms in the bacterial plaque metabolise carbohydrates, thus lowering the $\mathrm{pH}$ of the oral cavity and favouring the destruction of the hard tissues of the tooth ${ }^{58}$. On the other hand, a diet that is high in protein and fats reduces the risk of developing dental caries.
Schmorl's nodules are disc herniations through the vertebral body endplate into the adjacent vertebra and are usually considered to be the result of heavy mechanical loads to the spinal column ${ }^{59}$. All of the well-preserved thoracic and lumbar vertebrae of adult individuals were analysed for the frequency and distribution of this pathology.

Osteoarthritis is a degenerative joint disease that results in the degradation of articular cartilage and the loss of cartilage. Osteoarthritis is characterised by the progressive formation of osteophytes on the edges of the articular surface. The most common causes of osteoarthritis are physical activity and mechanical load to the joints ${ }^{60}$. For the purpose of this study, all cervical, thoracic and lumbar vertebrae were analysed.

All the skeletons in this study were macroscopically examined for the possible presence of trauma. The location, shape, dimension and possible complications were recorded for each injury. Also, a distinction between antemortem and perimortem injuries was made ${ }^{61}$.

Social status of the individuals was assessed according to grave finds and goods as well as grave architecture. Unlike archaeological finds in, for instance, refuse pits, finds in graves are deliberately and carefully selected to depict the social standing of the deceased person ${ }^{62}$. Numerous authors ${ }^{63-65 i n v e s t i g a t e d ~ t h e ~ a p p r o a c h ~ b a s e d ~ o n ~}$ the premise that the amount of labour invested in a particular burial, as well as the accompanying grave goods and other findings, is an indicator of social status. Archaeological data were collected after finishing the anthropological analysis in order to avoid possible effects on the estimation of sex, age and health status. Based on archaeological data relevant to grave architecture and the quality of grave goods and finds (not necessarily their quantity) the individuals were divided into four social groups (Table 1). Group 1 represents the poorest part of the society characterised by plain grave pits with very little, or no grave finds and goods. Groups 2 and 3 conditionally represent "the middle class" of society. Therefore, group 2 would depict "lower class" characterised by plain grave architecture (e.g. grave pit partially defined by stone) and very simple and modest finds - most often pottery and everyday objects (e.g. awls, knives, etc.). Group 3 corresponds to the wealthier stratum of society that is characterised by more complicated grave architecture (e.g. graves in the shape of a stone chamber or wooden coffins) and richer grave goods and finds (e.g. elaborate jewellery). Group 4 represents the most privileged, elite part of the society, and is identified through the presence of complicated grave architecture and/or very rich grave goods and finds (elite jewellery, Roman glass, equestrian equipment, etc.). As was expected the latter group was the least represented.

Data collected in archaeological and anthropological analyses were formed in variables then processed using the multivariate statistical method of log-linear analysis. Statistical analyses were performed by package StatSoft - Statistica program. 
TABLE 1

SOCIAL GROUPS DEFINED BY GRAVE ARCHITECTURE AND GRAVE FINDS AND GOODS

\begin{tabular}{ccc}
\hline Social group & Grave architecture & Grave finds and goods \\
\hline 1 & Plain grave pit & Very little or complete absence of grave finds and goods \\
2 & Plain grave pit, grave pit partially defined by stone & Pottery, everyday objects, simple jewellery \\
3 & Grave pit partially defined by stone, grave in the shape of & stone chest or coffin \\
4 & Wooden coffin, built tomb & Pottery, everyday objects, elaborate jewellery \\
& & $\begin{array}{c}\text { Abundance of grave goods and finds - pottery, everyday } \\
\text { objects, elaborate jewellery, equestrian equipment }\end{array}$ \\
\hline
\end{tabular}

\section{Results}

The sample consists of 216 individuals; 103 adult males, 99 adult females and 14 subadults under the age of 15. The average age at death of the people buried at the Early Medieval Nin - Ždrijac necropolis was 39.9 years ( $\mathrm{sd}=10.911)$, while analyses controlling for sex show that the average age at death for males was 41.5 years $(\mathrm{sd}=10.23)$ and for females 38.1 years ( $\mathrm{sd}=11.332)$.

The distribution of individuals according to sex and age groups and sex and social groups is shown in Tables 2 and 3.

Tables 4-9 show the distribution of analysed pathologies indicative of biological health of an individual with respect to sex and social status.

Log-linear analyses showed that there is no statistically significant correlation between the three tested varia-

TABLE 2

DISTRIBUTION OF INDIVIDUALS ACCORDING TO SEX AND AGE GROUPS

\begin{tabular}{ccccc}
\hline Age at death & Males & Females & Subadults & Total \\
\hline $0-5$ & 0 & 0 & 5 & 5 \\
$5-15$ & 0 & 4 & 9 & 13 \\
$15-30$ & 37 & 43 & 0 & 80 \\
$30-45$ & 31 & 31 & 0 & 62 \\
$45+$ & 35 & 21 & 0 & 56 \\
Total & 103 & 99 & 14 & 216 \\
\hline
\end{tabular}

TABLE 4

DISTRIBUTION OF CRIBRA ORBITALIA ACCORDING TO SEX AND SOCIAL GROUPS

\begin{tabular}{ccccccc}
\hline $\begin{array}{c}\text { CO / Social } \\
\text { group }\end{array}$ & Males & $\%$ & Females & $\%$ & Subadults & $\%$ \\
\hline 1 & $2 / 14$ & 14.3 & $4 / 14$ & 28.6 & $0 / 0$ & 0 \\
2 & $9 / 59$ & 15.3 & $11 / 46$ & 23.9 & $3 / 5$ & 60 \\
3 & $3 / 12$ & 25 & $3 / 14$ & 21.4 & $1 / 1$ & 100 \\
4 & $0 / 0$ & 0 & $0 / 0$ & 0 & $0 / 0$ & 0 \\
\hline
\end{tabular}

bles: sex, age and social status ( $\mathrm{p}$ values range from 0.41 to 0.29 ). However, the analyses showed that there is a statistical correlation between the variables 'age' and 'sex' $\left(X^{2}=47.517 ; p=0.000001\right)$ - males live significantly longer than females. Also, the Nin - Ždrijac sample exhibits fewer females over the age of 45 than is statistically expected in the age group 15-30 years and more males over 45 than is statistically expected in the sample. Furthermore, with respect to analysed pathologies that define health and life quality, log-linear analyses revealed that only the frequency and distribution of cribra orbitalia is correlated to sex $\left(\mathrm{X}^{2}=14.142 ; \mathrm{p}=0.006\right)$, but not to social status. None of the other analysed pathologies, dental enamel hypoplasia ( $p$ values range from 0.19 to 0.36 ), dental caries ( $p$ values range from 0.19 to 0.36 ), degenerative osteoarthritis ( $p$ values range from 0.77 to 0.22 ), Schmorl's nodes ( $p$ values range from 0.42 to 0.98 ), and trauma ( $\mathrm{p}$ values range from 0.20 to 0.43 ) are correlated to either sex or social status.
TABLE 3

DISTRIBUTION OF THE INDIVIDUALS ACCORDING TO SEX AND SOCIAL GROUPS

\begin{tabular}{crrcr}
\hline Social group & Males & Females & Subadults & Total \\
\hline 1 & 18 & 21 & 2 & 41 \\
2 & 64 & 58 & 10 & 132 \\
3 & 16 & 20 & 2 & 38 \\
4 & 5 & 0 & 0 & 5 \\
Total & 103 & 99 & 14 & 216 \\
\hline
\end{tabular}

TABLE 5

\begin{tabular}{ccccc}
\multicolumn{5}{c}{$\begin{array}{c}\text { DISTRIBUTION OF DENTAL ENAMEL HYPOPLASIA } \\
\text { ACCORDING TO SEX AND SOCIAL GROUPS }\end{array}$} \\
\hline DEH / Social group & Males & $\%$ & Females & $\%$ \\
\hline 1 & $3 / 15$ & 20 & $4 / 17$ & 23.5 \\
2 & $25 / 57$ & 43.9 & $17 / 49$ & 34.7 \\
3 & $8 / 14$ & 57.1 & $7 / 17$ & 41.2 \\
4 & $3 / 5$ & 60 & $0 / 0$ & 0 \\
\hline
\end{tabular}


V. Vyroubal et al.: Correlation Between Social Status and Health in Early Medieval Dalmatia, Coll. Antropol. 44 (2020) 2: 87-94

TABLE 6

\begin{tabular}{ccccccc}
\multicolumn{7}{c}{ DISTRIBUTION OF DENTAL CARIES ACCORDING TO } \\
$\begin{array}{c}\text { SEX AND SOCIAL GROUPS } \\
\begin{array}{c}\text { Caries / Social } \\
\text { group }\end{array}\end{array}$ Males & $\%$ & Females & $\%$ & Subadults & $\%$ \\
\hline 1 & $5 / 17$ & 29.4 & $11 / 19$ & 57.9 & $0 / 1$ & 0 \\
2 & $33 / 61$ & 54.1 & $25 / 53$ & 47.2 & $1 / 10$ & 10 \\
3 & $7 / 15$ & 46.7 & $6 / 19$ & 31.6 & $0 / 1$ & 0 \\
4 & $2 / 5$ & 40 & $0 / 0$ & 0 & $0 / 0$ & 0 \\
\hline
\end{tabular}

TABLE 8

DISTRIBUTION OF SCHMORL'S NODES ACCORDING TO SEX AND SOCIAL GROUPS

\begin{tabular}{ccccc}
\hline Schmorl / Social group & Males & $\%$ & Females & $\%$ \\
\hline 1 & $3 / 7$ & 42.9 & $0 / 4$ & 0 \\
2 & $2 / 16$ & 12.5 & $2 / 7$ & 28.6 \\
3 & $0 / 2$ & 0 & $0 / 0$ & 0 \\
4 & $1 / 1$ & 1 & $0 / 0$ & 0 \\
\hline
\end{tabular}

\section{Discussion and Conclusion}

Belonging to a social group and sharing its class characteristics were the main determinants in the material and spiritual life of medieval people. To some extent belonging to a social group was a pillar of personal security. Even those outside the group of the powerful and influential in the social community strove for social affiliation and the creation of groups with recognisable features/ characteristics.

The main hypothesis of this paper is that persons of lower social status lived in poorer living conditions than persons belonging to higher social classes. The stresses affecting an individual's health are inadequate nutrition, greater exposure and susceptibility diseases, generally worse living conditions, insufficient medical care, longterm severe physical labour, and the frequency and distribution of trauma. Health condition and health status changes are also visible after death in the skeletal remains. It is logical to assume that persons belonging to a higher social class were less exposed to pathogens that affect health and the quality of life than the persons of lower social status. The basic assumption of this paper is that the social status of the individual is reflected in his/ her funeral ritual and the quantity and quality of the archaeological artefacts they were buried with ${ }^{25,31}$. There were strict rules in most archaeological populations related to the burial of the deceased. The type of burial, grave architecture, position and orientation of the deceased, the horizontal stratigraphy, and the quantity and quality of the grave finds and goods reflect wealth, that is, the social status of the deceased ${ }^{32}$. In other words, the ritual by which the deceased is escorted out of this world
TABLE 7

DISTRIBUTION OF DEGENERATIVE OSTEOARTHRITIS ACCORDING TO SEX AND SOCIAL GROUPS

\begin{tabular}{ccccc}
\hline OA / Social group & Males & $\%$ & Females & $\%$ \\
\hline 1 & $7 / 11$ & 63.6 & $7 / 13$ & 53.8 \\
2 & $26 / 45$ & 57.8 & $12 / 28$ & 42.9 \\
3 & $9 / 13$ & 69.2 & $7 / 12$ & 58.3 \\
4 & $2 / 4$ & 50 & $0 / 0$ & 0 \\
\hline
\end{tabular}

\section{TABLE 9}

DISTRIBUTION OF TRAUMA ACCORDING TO SEX AND SOCIAL GROUPS

\begin{tabular}{ccccc}
\hline Trauma / Social group & Males & $\%$ & Females & $\%$ \\
\hline 1 & $0 / 18$ & 0 & $4 / 21$ & 19.1 \\
2 & $8 / 64$ & 12.5 & $7 / 58$ & 12.1 \\
3 & $0 / 16$ & 0 & $0 / 19$ & 0 \\
4 & $0 / 5$ & 0 & $0 / 0$ & 0 \\
\hline
\end{tabular}

is in accordance with the social position he/she enjoyed during their lifetime.

One of the main characteristics by which medieval society was divided was wealth, which largely corresponded to the class stratification of a society. Elite social groups regularly had relatively large fortunes at their disposal. The lower we move on a social scale towards the middle and lower segments of society, wealth becomes more modest, all the way to the layers of the deprived and the poor. The changes in property status and economic setbacks could affect all strata of society in the early Middle Ages, including members of the elite. The range between wealth and scarcity was the most noticeable feature of everyday life and manifested itself in almost all segments of material and spiritual life.

Reconstructing the social systems of archaeological populations is one of the important goals of archaeology. Social inequality has been a feature of human life since the advent of agriculture approximately 10.000 years ago ${ }^{66}$. The study of burial sites most often provides us with the richest source of data on social organisation and stratification of archaeological populations. The study of the material remains, i.e. grave architecture and contents of the graves (osteological material and grave goods) is the most common approach in the study of social stratification, i.e. the differences between individuals and the society they created and lived in. Graves (which is especially evident in grave goods and finds) are, unlike other archaeological finds (e.g. refuse pits) in principle carefully planned and designed, and as such depict one aspect of society, i.e., the social aspect of the perception of the deceased individual, but also the notion of death. Burial customs served as a ritual journey to the world of the dead 
and were manifested in the tomb architecture and the contributions ${ }^{67}$.

By combining the analyses of skeletal remains of a specific population with archaeological finds, we gain insight into the way of life of individuals in past societies, which allows us to shed light on several complex issues, such as the transition from a lifestyle of hunting and gathering to a sedentary lifestyle ${ }^{68}$, different sex and status based access to food ${ }^{11}$, and the influence that migrations, especially those of larger groups of people had on the quality of life of newcomers and indigenous people.

The analysis of the osteological material provides an insight into health, diet, lifestyle, specific activities, violence, exposure to diseases, and general demographic characteristics of a certain population ${ }^{69,70}$.Multivariate statistical analyses of the relationship between sex, life expectancy and affiliation to a certain social group showed that while there is a statistically significant correlation between the sex and age of an individual in the analysed sample, there was no such correlation between life expectancy and social status.

Research on social status and health conducted by Powell showed that grave finds and goods were not equally distributed among males, females, and all age groups, which leads to the conclusion that in the Mississippi culture of Moundville social status was inherited with birth. The results of preliminary analyses of strontium levels from the skeletal samples from Moundville suggest that members of the elite in that community consumed more meat than members of the lower classes, with meat consumption being generally higher in men than in women in all social categories. Our findings similarly show a pattern of higher frequencies of caries and cribra orbitalia in females which tentatively suggests the presence of a gender dictated diet in which females had less access to meat and instead derived most of their nutrition from carbohydrates. Similar research was conducted by Robb and associates analysing the archaeological population of Pontecagnano, dating between 7 th and 3rd century AD. The results of this research showed that the correlation between social status, activity and health is very complex. They observed that indicators considered typical of subadult stress (linear enamel hypoplasia, cribra orbitalia, and body height) were not related to social status. Quite surprisingly, indicators related to stress in adulthood (such as trauma, Schmorl's defects, the presence of periostitis) were associated with particular categories of grave goods. Consequently, in the Pontecagnano population, social status was not inherited (otherwise there would be marked differences in the frequency and distribution of pathologies associated with subadult stress, or inadequate nutrition during growth and development), but was acquired by merit (which confirms the fact that indicators indicating physical stress on the organism in adulthood were correlated with different grave attachments).

A multidisciplinary approach, combining the methods of three scientific disciplines (archaeology, anthropology, i.e. bioarchaeology and statistics) provides an insight into the lifestyle and the quality of life of the early Croats who inhabited Dalmatia during the early Middle Ages. The analyses conducted in this paper show that there was clear socio-economic differentiation in the early mediaeval Croatian society that manifested itself through marked differences in grave architecture, and the quantity and quality of associated grave goods. These differences were not, however, translated into significant differences in the frequencies of skeletal and dental markers of stress. Instead, the differences we identified seem to be primarily related to gender based differences in diet. Women from the lowest social group exhibit significantly higher incidences of caries, most likely as a result of a diet dominated by carbohydrates.

The purpose of this research was to establish whether social status had a direct impact on biological health in Early Medieval Dalmatia. Looking at the results of the log-linear analyses it became evident that the privileged and the underprivileged were exposed to the same pathogens, and therefore shared very similar living conditions.

\section{R E F E R E N C E S}

1. VIDANOVIĆ I, Rječnik socijalnog rada (General Books, LLC, 2006). -2. RAUKAR T, Hrvatsko srednjovjekovlje: prostor, ljudi, ideje (Školska knjiga: Zavod za hrvatsku povijest Filozofskog fakulteta, Zagreb, 1997). —3. LEUTAR Z, ŠTAMBUK A, Hrvat Rev Za Rehabil, 43 (2007) 47. — 4. GOLDMAN N, Social Inequalities in Health: Disentangling the Underlying Mechanisms. In: Conference Proceedings of the Seminar (Demography and Epidemiology: Frontiers in Population Health and Aging, Georgetown University,Washington D.C., 2001). - 5. BARTLEY M, Health Inequality: an introduction to theories, concepts, and methodism (Polity Press, Cambridge, 2004). - 6. WONG MD, SHAPIRO MF, BOSCARDIN WJ, ETTNER SL, N Engl J Med, 347(2002) - 7. MONTGOMERY J, BUD P, EVANS J, Eur J Archaeol, 3 (2000) 370. - 8. GOLDMAN N, Social Inequalities in Health: Disentangling the Underlying Mechanisms. Conference Proceedings of the Seminar on "Demography and Epidemiology: Frontiers in Population Health and Aging," (Georgetown University,Washington D.C. February 9-10, 2001. New York Academy of Sciences 2001). - 9. ERIKSEN HR, URSIN H, Scand J Psychol, 43 (2002) 189. - 10. HUGHES, C., HWANG, R., KIM, J.H., EISENMAN, L.T., KILLIAN, D.J. Am J Ment
Retard, 99 (1995) 623. - 11. POWELL ML, Status and Health in Prehistory: A Case Study of the Moundville Chiefdom (Smithsonian Institution Press, Washington, 1998). - 12. PEEBLES CS, Mem Soc Am Archaeol, 25 (1971) 68. - 13. PEEBLES CS, KUS S, Am Antiq, 42(1977) 421. BIGAZZI R, LAZZARINI L, SCARSINI C, SONEGO F, Am J Phys Anthropol, 115 (2001) 213. - 15. BECKER GS, Human Capital: A Theoretical and Empirical Analysis, with Special Reference to Education; 3RD edition (University of Chicago Press, Chicago, 1964, 1993). - 16. CAPASSO L, BAGGIERI G, DI TOTA G, MEUCCI C, Antropol Contemp, 17 (1994) 13. — 17. FORNACIARI G, BROGI M, BALDUCCI E, Ossa, 12 (1985-1986) 9. - 18. GERMANÀ F, FORNACIARI G, Trapanazioni, craniotomie e traumi cranici in Italia dalla Preistoria all'Età moderna (Giardini Editori e Stampatori, Pisa, 1992). — 19. LOMBARDI PARDINI E, POLOSA D, PARDINI E, Arch per l'antrop, 114 (1984) 3. - 20. PETRONE PP, Analisi paleodemigrafica e paleopatologica delle tombe in proprieta Rosso-mando. In: SERITELLA A (Ed): Pontecagnan: Le nuove aree di necropolis del IV e III sec. a.C. (Istituto Universitario Orientale, Naples, 1995). - 21. SKEATES R, J Eur Arch, 2 (1994) 199. — 22. ROBB J, Violence and gender 
in early Italy. In: MARTIN DW, FRAYER DL (Eds): Troubled times: Violence and Warfare in the Past (War and Society) (Gordon and Breach, Amsteradam, 1997). - 23. ROBB J, Int J Osteoarchaeol, 8 (1998) 363. 24. SCARSINI C, BIGAZZI R, Studio antropologico dei resti umani. In: SERITELLA A (Ed) Pontecagnan: Le nuove aree di necropolis del IV e III sec. a.C. (Istituto Universitario Orientale, Naples, 1995). - 25. SONEGO F, SCARSINI C, Bulletino di Paletnologia italiana, 85 (1994) 1. - 26. SAXE AA, Social Dimensions of Mortuary Practices in a Mesolithic Population from Wadi Halfa, Sudan (Society of American Archaeology, New York, 1971). - 27. JANKAUSKAS R, Int J Osteoarchaeol, 13 (2003) 289. -28. SCHERER AK, WRIGHT LE, YODER CJ, Lat Am Antiq, 18 (1), 20, (2007) 85. - 29. REDFREN RC, DEWITTE SN, Am J Phys Anthropol, 2 197 (2001) - - 30. BUZON MR, Health of the Non-Elites at Tombos: Nutritional and Disease Stress in New Kingdom Nubia (Department of Anthropology, University of Alberta Edmonton, Alberta, Edmonton, 2006). - 31. BUZON RM, JUDD MA, Am J Phys Anthropol, 136 (2008) 93. - 25. SAXE AA, Social Dimension of Mortuary Practices. PhD Thesis. In USA (University of Michigan, Michigan, 1970). - 32. BINFORD LR, Approaches to the Social Dimensions of Mortuary Practices, Memoirs of the Society for American Archaeology, 25 (1971) 6. — 33. O'SHEA J, Mortuary Variability: An Archaeological Investigation (Academic Press.Inc.Orlando, Florida, 1984). - 34. BELOŠEVIĆ J, Arh Pregl, 11 (1969) 217. — 35. BELOŠEVIĆ J, Materijalna kultura Hrvata od 7. do 9. stoljeća(Sveučilišna naklada Liber, Zagreb, 1980). - 36. BELOŠEVIĆ J, Starohrvatsko groblje na Ždrijacu u Ninu (Arheološki muzej, Zadar, 2007). - 37. KROGMAN WM, IŞCAN MY, The Human Skeleton in Forensic Medicine, 2nd ed. (CC Thomas, Springfield, 1986). - 38. BASS WM, Human Osteology, A Laboratory and Field Manual of the Human Skeleton, 3rd ed. (Missouri Archaeological Society, Columbia, 1987). - 39.BRUZEK J, Am J Phys Anthropol, 117 (2002) 157. — 40. BROOKS S, SUCHEY JM, Hum Evol, 5 (1990) 227. — 41. LOVEJOY CO, MEINDL RS, PRYZBECK TR, MENSFORTH RP, Am J Phys Anthropol, 68 (1985) 15. - 42. MEINDL RS, LOVEJOY CO, Am J Phys Anthropol, 68 (1985) 57. - 43. IŞCAN MY, LOTH SR, WRIGHT RK, J Forensic Sci, 29 (1984) 1094. — 44. IŞCAN MY, LOTH SR, WRIGHT
RK, J Forensic Sci, 30 (1985) 853. - 45. SMITH BH, Am J Phys Anthropol,63 (1984) 39. - 46. MOORREES CFA, FANNING EA, HUNT EE, J Dent Res, 42 (1963) 1490.- 47. SCHEUER L, BLACK S, Developmental Juvenile Osteology (Academic Press, New York, 2000). - 48. HENGEN OP, Homo, 22 (1971) 57. — 49. MENSFORTH RP, LOVEJOY CO, LALLO JW, ARMELAGOS GJ, Med Anthropol, 2 (1978) 1. - 50. WOLTER JR, J Pediat Ophth Strab, 16 (1979) 291. - 51. GRIFFETH MT, DAILEY RA, OFNER S, ArchOphthalmol, 115 (1997) 679. - 52. SARNAT BG, SCHOUR IS, J Am Dent Assoc, 29 (1941) 67. - 53. PINDBORG JJ, Pathology of the dental hard tissues (WB Saunders, Philadelphia, 1970). - 54. GOODMAN HA, ARMELAGOS GJ, Am J Phys Anthropol, 68 (1985) 479. — 55. GOOD MAN HA, ROSE JC, Yearb Phys Anthropol, 33 (1990) 59. - 56. GOODMAN AH, ARMELAGOS GJ, ROSE JC, Hum Biol, 52 (1980) 515. — 57. KRESHOVER SJ, Ann N Y Acad Sci, 85 (1960) 161. - 58. LARSEN CS, Bioarchaeology. Interpreting behavior from the human skeleton (Cambridge University Press, Cambridge, 1997). - 59. POWELL ML, The analysis of dental wear and caries for dietary reconstruction (Academic Press, New York, 1985). - 60. SCHMORL G, JUNGHANNS H, The Human Spine in Health and Disease (Grune and Stratton, New York, 1971). - 61. HOUGH AJ, SOKOLOFF L, Pathology of osteoarthritis (Lea and Febiger, Philadelphia, 1989). - 62. LOVELL NC, Am J Phys Anthropol, 104 (1997) 139. - 63. JAMES E, Transactions of the Royal Historical Society, 39 (1989) 23. - 64. PARKER PEARSON M, Camb Archaeol J, 3 (1993) 203. - 65. RENFREW C, BAHN P, Archaeology: Theories, Methods and Practice (Thames and Hudson, London, 2000). - 66. CHRISTLEIN, R, Materialhefte zur bayerischen Vorgeschichte 21 (1966). - 34. THOMAS DH, Archaeology (Harcourt Inc., Orlando,1998). — 67. FAGAN BM, DEC ORASE CR, In the begining: An Introduction to Archaeology (Pearson Prentice Hall, New Jersey, 2005). - 68. BOGIN B, Patterns of Human Growth (Cambridge University Press, Cambridge, 1999). — 69. LARSEN CS, Bioarchaeology (Cambridge University Press, Cambridge, 1997). - 70. LARSEN CS, Journal of Archaeological Research, 10 (2002) 119.

\section{Vyroubal}

Anthropological Center, Croatian Academy of Sciences and Arts, Ante Kovačića 5, 10000 Zagreb, Croatia e-mail:vyroubal@hazu.hr

\section{KORELACIJA IZMEĐU DRUŠTVENOG STATUSA I ZDRAVLJA U DALMACIJI RANOG SREDNJEG VIJEKA}

\section{S A Ž E T A K}

Razdoblje ranog srednjeg vijeka gotovo se uopće ne spominje u povijesnim izvorima. Društvena zajednica imala je vrlo bitnu ulogu u razvoju ranosrednjovjekovnog društva u Hrvatskoj. Unutar svake zajednice postojalo je mnoštvo razlika, a način i vrsta zajednice ovisili su o mnogo čimbenika. Pripadnost društvenoj grupi i njene staleške karakteristike bile su glavne odrednice u materijalnom i misaonom životu srednjovjekovnog čovjeka. Proces raslojavanja i stvaranja socijalnih grupa u Hrvatskoj u razdoblju ranog srednjeg vijeka bio je višestruko neujednačen, a najbrži i najpotpuniji je bio na društveno najrazvijenijem području, odnosno istočnoj obali Jadrana. U radu su prikazani rezultati antropološke analize zdravlja i kvalitete života starohrvatske populacije pokopane na nalazištu Nin - Ždrijac, u kontekstu socijalnog statusa. Temeljna pretpostavka jest da su osobe koje su pripadale različitim socijalnim grupama unutar zajednice uživale i različite životne prilike, što se onda odražavalo i na njihovo zdravlje i kvalitetu života, u smislu doživljene starosti. Socijalni status pokojnika određivao se pomoću arheološkog konteksta, odnosno karakteristika ukopa, a pod pretpostavkom da se socijalni status pokojnika odražavao i u načinu ukopa. Kriteriji koji su se pritom koristili su grobna arhitektura, te količina i vrsta grobnih priloga i nalaza. Kako bi se odredilo zdravstveno stanje pokojnika korištene su antropološke metode, što je uključivalo analize spola i starosti, te patologija koje ostavljaju traga na kostima. Za određivanje korelacija parametara koji određuju biološko zdravlje s parametrima koji određuju socijalni status korištene su multivarijatne log-linearne analize. 
